\title{
Estrous cycle dependent changes in expression and distribution of Fas, Fas ligand, Bcl-2, Bax, and pro- and active caspase-3 in the rat ovary
}

\author{
Karin A Slot ${ }^{1}$, Marsha Voorendt ${ }^{1}$, Mieke de Boer-Brouwer ${ }^{1}$, \\ Harmke $H$ van Vugt ${ }^{2}$ and Katja J Teerds ${ }^{1,2}$ \\ ${ }^{1}$ Department of Biochemistry \& Cell Biology, Faculty of Veterinary Medicine, Utrecht University, Yalelaan 2, 3508 TD Utrecht, The Netherlands \\ ${ }^{2}$ Human and Animal Physiology Group, Department of Animal Sciences, Wageningen University, Haarweg 10, \\ 6709 PJ Wageningen, The Netherlands \\ (Requests for offprints should be addressed to K J Teerds; Email: katja.teerds@wur.nl)
}

\begin{abstract}
In the present investigation, the localization of proteins involved in ovarian apoptosis were studied throughout the estrous cycle in the presence of fluctuating hormone levels. Fas, Fas ligand, Bcl-2, Bax and caspase-3 mRNA expression and proteins were detected in all ovarian tissue extracts, though the amount of protein varied with the phase of the estrous cycle. Fas, Bax and caspase- 3 protein levels were highest at diestrus and decreased thereafter towards metestrus. In contrast, Fas ligand and $\mathrm{Bcl}-2$ protein levels were lowest at diestrus and increased toward metestrus. Immunohistochemistry revealed that the staining of the anti-apoptotic protein $\mathrm{Bcl}-2$ was more pronounced in healthy preantral follicles than in atretic follicles. In contrast, the pro-apoptotic proteins Fas, Fas ligand, Bax and active caspase- 3 were more predominantly present in atretic follicles. In the ovarian
\end{abstract}

surface epithelium (OSE), Fas, procaspase-3 and Bcl-2 immunostaining appeared independent of the phase of the estrous cycle. Fas ligand and Bax staining was detected particularly during proestrus in OSE cells surrounding the ovulatory follicles, while active caspase-3 was observed only in OSE cells at the postovulatory site during estrus. The proportion of luteal cells that stained positively for Fas, Bax and caspase- 3 increased with the age of the corpus luteum, while Fas ligand and Bcl-2 immunostaining was strongest in newly formed corpora lutea and decreased thereafter. In conclusion, the components of the Fas signalling pathway were differentially expressed throughout the estrous cycle in a variety of ovarian cell types, which may correspond to hormone dependent survival mechanisms.

Journal of Endocrinology (2006) 188, 179-192

\section{Introduction}

Programmed cell death or apoptosis is an essential component of normal reproductive function and development in the ovary. Most importantly, apoptosis attributes to the exhaustion of the oocyte reserve, either directly through germ cell death or indirectly through follicular atresia (Hsueh et al. 1994). In this regard, apoptosis has been proposed to be the major mechanism that determines female reproductive life span (Tilly 2001). Indeed, it has been shown that inhibition of apoptosis by selectively disrupting Bax function in female mice was accompanied by an increased primordial follicle pool size and a prolonged ovarian life span (Perez et al. 1999). Hence, a better understanding of programmed cell death in the ovary may help to develop novel therapies to treat females with ovarian disorders such as premature ovarian failure.

Throughout life, dormant primordial follicles are continuously recruited from the resting pool to start growing.
Until puberty, these follicles do not survive beyond the early antral stage. In postpubertal females, however, some early antral follicles may become selected during each estrous cycle and continue growth under the influence of elevated FSH levels (McGee \& Hsueh 2000). Among this cohort, depending on the species, one or a few large antral follicles will reach the preovulatory stage and ovulate following the LH surge, whereas the remaining antral follicles that have been recruited during this growth wave will degenerate as a result of follicular atresia (Hsueh et al. 1994). Atresia, a process which involves apoptosis of granulosa cells, oocytes and eventually theca cells, can occur during any stage of follicular development, although early antral follicles are most vulnerable to undergo follicular degeneration (Hsueh et al. 1994, Markstrom et al. 2002). During each estrous cycle, other ovarian cell types in addition to follicular cells may also undergo apoptosis. Ovarian surface epithelial (OSE) cells covering the protruding preovulatory follicles degenerate from the 
ovarian surface by apoptosis just prior to ovulation, to facilitate the release of the oocyte (Murdoch \& McDonnel 2002). Moreover, corpora luteal cells arising from the ovulatory follicles undergo apoptosis during luteal regression, when ovulation is not associated with a fertile mating and implantation of the conceptus (Sakamaki et al. 1997, Kuranaga et al. 1999).

The role of proteins and genes involved in the regulation of apoptosis in the ovary is relatively well understood. However, the hormonal factors that trigger apoptosis in the various ovarian cells types during the estrous cycle are not yet clearly defined. The major players of apoptosis in the ovary are assumed to be the Fas system and the Bcl-2 family members (Guo et al. 1994, Kondo et al. 1996, Kugu et al. 1998, Kim et al. 1999, Roughton et al. 1999). It has been suggested that interaction between the Fas system and Bcl-2 family members may define the rate of apoptosis (Krammer 1999). Fas receptor (Fas/CD95) is a member of the tumor necrosis factor/nerve growth factor family, which is activated upon binding Fas ligand, leading to receptor aggregation and formation of a death-inducing signalling complex (DISC) (Krammer 1999). Once Fas has been activated, two distinct intracellular apoptotic pathways can be executed, depending on the level of released active caspase-8 (Fig. 1) (Scaffidi et al. 1998). In type I cells, high levels of caspase- 8 at the DISC directly initiate cleavage of other downstream effector caspases, such as caspase-3, thereby initiating the execution phase of apoptosis. In type II cells, however, a small caspase-8 signal is generated, which in order to induce apoptosis, requires an amplification loop via the mitochondria involving cleavage of the pro-apoptotic Bcl-2 family member Bid (Scaffidi et al. 1998). It has been proposed that cleaved Bid stimulates dimeric binding of other pro-apoptotic $\mathrm{Bcl}-2$ family members (e.g. Bax and Bak) to the mitochondria at the expense of anti-apoptotic Bcl-2 family members (e.g. $\mathrm{Bcl}-2, \mathrm{Bcl}-\mathrm{w}, \mathrm{Bcl}-\mathrm{x}_{\mathrm{L}}$ ). This triggers cytochrome $\mathrm{c}$ release, which eventually results in downstream activation of effector caspases and cell death (Krammer 1999).

Several studies have demonstrated the presence of Fas and Fas ligand during follicular atresia (Guo et al. 1994, Hakuno et al. 1996, Kondo et al. 1996, Kim et al. 1999, Cataldo et al. 2000, Dharma et al. 2003) and luteal regression (Sakamaki et al. 1997, Roughton et al. 1999). However, controversy exists about the distribution of these proteins during follicular development. The differences among these studies may in part be explained by the different experimental models used for the induction of apoptosis. In these models, apoptosis is often-induced artificially, for instance by gonadotrophin withdrawal or treatment with prostaglandin $\mathrm{F}_{2 \alpha}$. This type of induced degeneration may differ in key aspects from normal spontaneous atresia or luteal regression. In fact, little is known regarding expression of either Fas or other components associated with Fas signalling under normal physiological conditions during the estrous cycle.

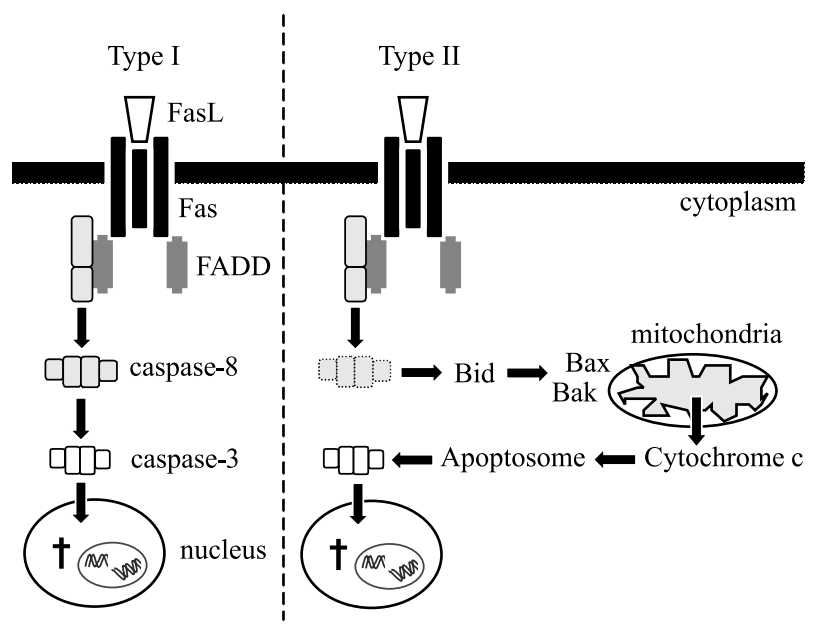

Figure 1 Schematic overview of Fas-induced apoptosis in type I and II cells. Fas is activated upon binding to Fas ligand, resulting in receptor trimerization and the recruitment of adapter proteins. When procaspase- 8 becomes associated, it is autoproteolytically cleaved into active subunits that are released into the cytoplasm. In type I cells, active caspase- 8 might then act directly to cleave other effector caspases, such as caspase-3, thereby initiating the execution phase of apoptosis. In type II cells, however, active caspase- 8 cleaves Bid, a proapoptotic member of the Bcl-2 family. Cleaved Bid stimulates the binding of proapaptotic $\mathrm{BCl}-2$ proteins (Bax, Bak) to the mitochondria and inhibits association of anti-apoptotic $\mathrm{Bcl}-2$ proteins (e.g. $\mathrm{Bcl}-2, \mathrm{Bcl}-\mathrm{w}, \mathrm{BCl}-\mathrm{x}_{\mathrm{L}}$ ). This causes leakage of cytochrome $\mathrm{c}$ from the mitochondria into the cytosol, which in turn promotes formation of the apoptosome and triggers caspase-3. The activation of caspase- 3 is considered to be the final executioner step in apoptosis and is responsible for cleavage of key substrates, such as DNA repair enzymes and cytoskeletal and nuclear scaffold proteins. Scheme adapted from Scadiffi and colleagues (Scaffidi et al. 1998).

Furthermore, the simultaneous assessment of relevant apoptotic proteins in the whole ovary throughout the estrous cycle has not been reported so far. We, therefore, investigated the localization and distribution of the Fas system and its related proteins, i.e. Fas, Fas ligand, Bcl-2, Bax, pro- and active caspase-3, during normal follicular development, atresia, ovulation and luteolysis in the rat throughout the estrous cycle. Furthermore, the corresponding mRNA expression and protein levels in whole rat ovaries were determined.

\section{Materials and Methods}

\section{Reagents}

Antibodies against Fas receptor (sc-715), Fas ligand (sc-956), procaspase-3 (sc-492), Bcl-2 (sc-1226), Bax (sc-526), and actin (sc-1616) were purchased from Santa 
Cruz Biotechnology (SanverTech, Heerhugowaard, the Netherlands). The antibody against active caspase-3 (AF835) that detects only cleaved caspase-3 was obtained from R\&D systems (ITK Diagnostics, Uithoorn, The Netherlands), while the antibody against caspase-3 used for Western blot analysis, which detects both the caspase-3 precursor of $32 \mathrm{kDa}$ and the cleaved active caspase-3 fragment of $20 \mathrm{kDa}$, was obtained from Cell Signalling Technology (Westburg BV, Leusden, The Netherlands). Secondary biotinylated goat-anti-rabbit, rabbit-anti-goat or goat-anti-mouse IgG's were purchased from Vector Laboratories (Vectastain kit Elite; Vector Laboratories, Burlingame, CA, USA), while horseradish peroxidaseconjugated goat-anti-rabbit $\operatorname{IgG}$ was obtained from Nordic Immunological Laboratories (Tilburg, The Netherlands). TRIzol reagent, acetylated BSA and 3,3'-diaminobenzidine tetrachloride were purchased from Gibco BRL (Invitrogen Life Technologies), Aurion (Wageningen, The Netherlands) and Sigma, respectively. The avidin-biotin complex (ABC)-peroxidase complex staining kit Elite was purchased from Vector Laboratories, the in situ cell death detection kit for TUNEL labelling was bought from Roche Diagnostics GmbH, while the Coomassie Plus protein assay reagent kit and supersignal chemiluminescent substrate kit (ECL) were bought from Pierce (Tattenhall, Cheshire, UK). The ImProm-II reverse transcription system kit, oligo dT primer, dNTPs and RQ1 Rnase-Free Dnase were obtained from Promega Corporation.

\section{Animals}

Female outbred Wistar rats (Harlan, Horst, The Netherlands) were housed in pairs and kept in a temperature- and light-controlled room (12 h light:12 h darkness) with free access to food and water. Estrous cycles were tracked by carrying out daily vaginal smears, and only the rats that showed two consecutive 4-day cycles were used for the experiments. A total of twenty three 16 to 19 -week-old animals were sacrificed at four different stages of the estrous cycle, i.e. diestrus $(n=6)$, proestrous $(n=6)$, estrus $(n=6)$ and metestrus $(n=5)$. The ovaries were carefully excised to avoid damage to the OSE. After excision, the left ovaries of 8 of these animals (two animals for each stage of the estrous cycle) were snap frozen in liquid nitrogen and stored at $-80{ }^{\circ} \mathrm{C}$ until use for RT-PCR and immunoblot analysis $(n=8)$. The right ovaries of these 8 animals were processed for immunohistochemical analysis together with the ovaries of the other 15 rats. These ovarian tissues were fixed for $24 \mathrm{~h}$ in $4 \%$ buffered formalin, embedded in paraffin and stored at room temperature until immunohistochemical processing. The experiments described in the present study have been approved by the ethical committee for animal welfare of Wageningen University (Wageningen. The Netherlands).

\section{Reverse transcription-PCR (RT-PCR)}

The TRIzol method was used to extract total RNA from snap-frozen rat ovaries according to the manufacturer's instructions. RNA integrity was confirmed by running $2 \mu \mathrm{g}$ RNA on a $1 \%$ agarose denaturing gel. The amount of RNA was estimated by spectophotometry at $260 \mathrm{~nm}$. Prior to RT-PCR, RNA samples were treated with RQ1 RNase-Free DNase, then purified by phenol-chloroform extraction followed by precipitation with ethanol. RTPCR was performed in $20 \mu \mathrm{l}$ reaction mixture containing $1 \mu \mathrm{g}$ total DNase-treated RNA, 0.5 $\mu \mathrm{g}$ oligo dT primer, $0.5 \mathrm{mM}$ dNTPs, $5 \mathrm{mM} \mathrm{MgCl}_{2}, 4 \mu \mathrm{l}$ ImProm-II $5 \times$ reaction buffer and $1 \mu \mathrm{l}$ ImProm-II reverse transcriptase at $42{ }^{\circ} \mathrm{C}$ for $60 \mathrm{~min}$. Then, reverse transcriptase was inactivated by heating at $75^{\circ} \mathrm{C}$ for $15 \mathrm{~min}$. The synthesized complementary DNA was stored at $-80^{\circ} \mathrm{C}$ until use. The PCR was carried out in $50 \mu \mathrm{l}$ reaction mixture prepared on ice which contained $5 \mu \mathrm{l} 10 \times$ thermophilic reaction buffer, $1 \mathrm{U}$ Taq polymerase, $2 \mathrm{mM} \mathrm{MgCl}_{2}$, $0.2 \mathrm{mM}$ dNTP, PCR buffer, $0.5 \mu \mathrm{M}$ upstream primer, $0 \cdot 5 \mu \mathrm{M}$ downstream primer and $1 \mu \mathrm{l}$ reverse transcription mixture (cDNA). The PCR primers used for amplification were synthesized by Isogen Bioscience on the basis of the rat DNA sequences described earlier for Fas (Kimura et al. 1994), Fas ligand (Suda et al. 1993), caspase-3 (Omezzine et al. 2003), GAPDH (Duvigneau et al. 2003), Bcl-2 and Bax (Sato et al. 1994, Tilly et al. 1995). The PCR conditions were $94{ }^{\circ} \mathrm{C}$ for $5 \mathrm{~min}$ followed by 40 cycles of $94^{\circ} \mathrm{C}$ for $45 \mathrm{sec}, 55^{\circ} \mathrm{C}$ for $60 \mathrm{~s}$, and $72{ }^{\circ} \mathrm{C}$ for $45 \mathrm{~s}$, respectively and then $72{ }^{\circ} \mathrm{C}$ for $5 \mathrm{~min}$. After amplification, $10 \mu \mathrm{l}$ of the PCR products were separated by electrophoresis on $1.5 \%$ agarose gels containing $0.002 \%$ ethidium bromide, visualized by u.v. light and photographed. The equal loading of the samples was demonstrated by RT-PCR analysis of the housekeeping gene GAPDH. Negative controls (reactions without reverse transcriptase and reactions without template) were performed to verify the absence of (DNA) template contamination. No products were observed in these control reactions.

\section{Western blot analysis}

Protein samples were prepared from snap-frozen rat ovaries using TRIzol reagent according to the manufacturer's instructions. Protein concentrations were determined by the Bradford assay (Bradford 1976) with the Coomassie Plus protein assay reagent kit and resolved in SDS-sample buffer (62.5 mM Tris, $2 \%$ SDS, $10 \%$ glycerol, $1 \% \beta$-mercaptoethanol and 0.003\% Bromophenol Blue, $\mathrm{pH} 6.8$ ) in a final concentration of $500 \mu \mathrm{g} / \mathrm{ml}$. After boiling the samples for $10 \mathrm{~min}$, the proteins $(10 \mu \mathrm{g} / \mathrm{lane})$ were separated by $12 \%$ SDS-PAGE and transferred onto nitrocellulose membranes. The membranes were blocked with $5 \%$ non-fat dry milk in TTBS $(10 \mathrm{mM}$ Tris $\mathrm{pH} 7 \cdot 5$, 
$100 \mathrm{mM} \mathrm{NaCl}, 0 \cdot 1 \%$ Tween-20) for $1 \mathrm{~h}$, and incubated overnight at $4{ }^{\circ} \mathrm{C}$ with a rabbit-anti-human polycloncal antibody against Fas and Fas ligand (diluted 1:500); caspase- 3 (which reacts with both the $32 \mathrm{kDa}$ pro-enzyme and the spliced $20 \mathrm{kDa}$ active form of caspase-3, diluted 1:500), Bcl-2 and Bax (diluted 1:250), or with a goat anti-human polyclonal antibody against actin (diluted 1:1000) in blocking buffer. After washing three times with TTBS, the membranes were incubated for 1 hour with horseradish peroxidase-conjugated goat-anti-rabbit IgG (Fas, Fas ligand, caspase-3, Bcl-2 and Bax) diluted 1:15000 or rabbit-anti goat IgG (actin) diluted 1:5000 in blocking buffer. The presence of antibody-protein complexes was detected by ECL. Relative quantification of ECL signals on films was performed using a two-dimensional scanning image densitometer (model GS-700; BIO-RAD Laboratories) followed by band analysis using Quantity One software version $4 \cdot 2 \cdot 1$. Values are expressed as mean density ratio \pm S.E.M. relative to that of the respective diestrus values from three independent experiments. Due to differences in exposure time of the separate blots and the fact that the intensity of the protein bands is, in part, dependent on the duration of the exposure time, no statistical analysis of the densitometric data was performed.

\section{Immunohistochemistry}

Immunohistochemistry was performed as described by Teerds \& Dorrington (1995). Briefly, $5 \mu \mathrm{m}$ thick paraffin embedded ovarian sections were deparaffinized and treated with $1 \% \mathrm{H}_{2} \mathrm{O}_{2}$ in methanol for 30 min to block endogenous peroxidase activity. The slides were subsequently washed in 0.01 M Tris-buffered saline (TBS pH $7 \cdot 4$ ), microwaved in buffered citrate for $10 \mathrm{~min}$ (only in case of procaspase-3), incubated with $0 \cdot 1 \mathrm{M}$ glycine in TBS for $30 \mathrm{~min}$, and rinsed with TBS. Sections were blocked for $30 \mathrm{~min}$ with $10 \%$ normal goat or rabbit serum, and incubated at $4{ }^{\circ} \mathrm{C}$ overnight with rabbit-antihuman polycloncal antibodies against Fas, Fas ligand, Bcl-2, Bax (all diluted 1:200), active caspase-3 (concentration $10 \mu \mathrm{g} / \mathrm{ml}$ ), or with a goat-anti-human polyclonal antibody against procaspase-3 (diluted 1:100), respectively. A pilot experiment had revealed that these dilutions of the antibodies resulted in optimal staining. All antibodies were diluted in TBS containing 0.05\% acetylated BSA. Slides were again washed in TBS and incubated for $60 \mathrm{~min}$ with the corresponding biotinylated goat-antirabbit or rabbit anti-goat IgGs respectively, diluted 1:200 in TBS containing 0.05\% acetylated BSA. Sections were subsequently washed in TBS and incubated for at least 60 min with the components avidin (A) and biotin (B) of the $\mathrm{ABC}$ staining kit Elite. Both components (A and $\mathrm{B}$ ) were diluted 1:1000 and the solution was prepared at least $15 \mathrm{~min}$ before use. Slides were washed in TBS, rinsed in $0.05 \mathrm{M}$ Tris- $\mathrm{HCl}(\mathrm{pH} 7 \cdot 5)$ and finally bound antibody was visualized after the addition of a $0.6 \mathrm{mg} / \mathrm{ml}$ solution of 3,3'-diaminobenzidine tetrachloride (DAB) in Tris- $\mathrm{HCl}$ to which $0 \cdot 03 \% \mathrm{H}_{2} \mathrm{O}_{2}$ was added. The slides were subsequently counterstained with Mayer's haematoxylin. Control sections, in which the primary antibody was replaced by either normal rabbit or goat serum, were similarly processed. No staining was observed in these controls (Fig. 5 G). For each primary antibody, the intensity of immunostaining was determined by estimating the percentage of positively-labelled cells. The intensity of immunostaining was assigned as being absent $(-)$, faint $(-/+)$, moderate $(+)$ and high $(++)$ when respectively $<1$, $1-10,10-50,50-100$ percent of the cells in the follicular or corpus luteum cross section stained positively. All OSE cells covering the surface of the ovary were counted.

The immunohistochemical staining procedures for each antibody were repeated at least 6 times on all 23 ovaries analyzed in this study.

\section{In situ DNA labelling for apoptosis}

The laboratory protocol for TUNEL (terminal deoxynucleotidyl transferase-mediated dUTP nick end-labelling) was used according to the manufacturer's instructions with some minor modifications adapted from Negoescu and colleagues. (Negoescu et al. 1996). Briefly, paraffin embedded ovarian sections were deparaffinized, microwaved in buffered citrate for $5 \mathrm{~min}$, cooled rapidly and rinsed in PBS ( $\mathrm{pH} 7 \cdot 4)$. The slides were covered with the TUNEL reaction mixture (1:10 dilution of an enzyme solution containing calf thymus terminal deoxynucleotidyl transferase and label solution containing a nucleotide mixture of digoxigenin-11-2'-dUTP) for $60 \mathrm{~min}$ at $37^{\circ} \mathrm{C}$. Then, slides were blocked for $30 \mathrm{~min}$ with $5 \%$ non-fat dry milk and $10 \%$ normal horse serum in PBS. The slides were subsequently washed in PBS and incubated with a 1:4 dilution of peroxidase-labeled digoxigenin sheep Fab antibody for 30 min at $37 \mathrm{C}$. After washing the sections in PBS, the DNA strand breaks were visualized with a $\mathrm{DAB}$ color reaction, and counterstained with Mayer's hematoxylin, as described above. Negative controls, by omitting terminal deoxynucleotidyl transferase TdT, were similarly processed. No staining was observed in these negative controls (data not shown).

\section{Results}

Expression of the Fas system in whole rat ovaries throughout the estrous cycle

To examine the presence of Fas receptor and signalling molecules throughout the estrous cycle, we determined their presence in whole rat ovarian tissue extracts at diestrus, proestrus, estrus and metestrus. Fas, Fas ligand, caspase-3, Bcl-2 and Bax mRNA and protein were detected by RT-PCR and Western blot analysis, respectively 
$\mathbf{A}$

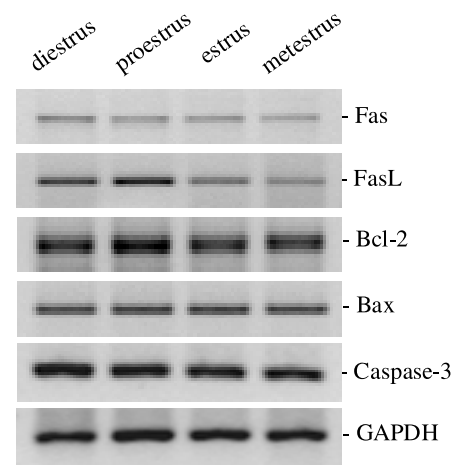

B

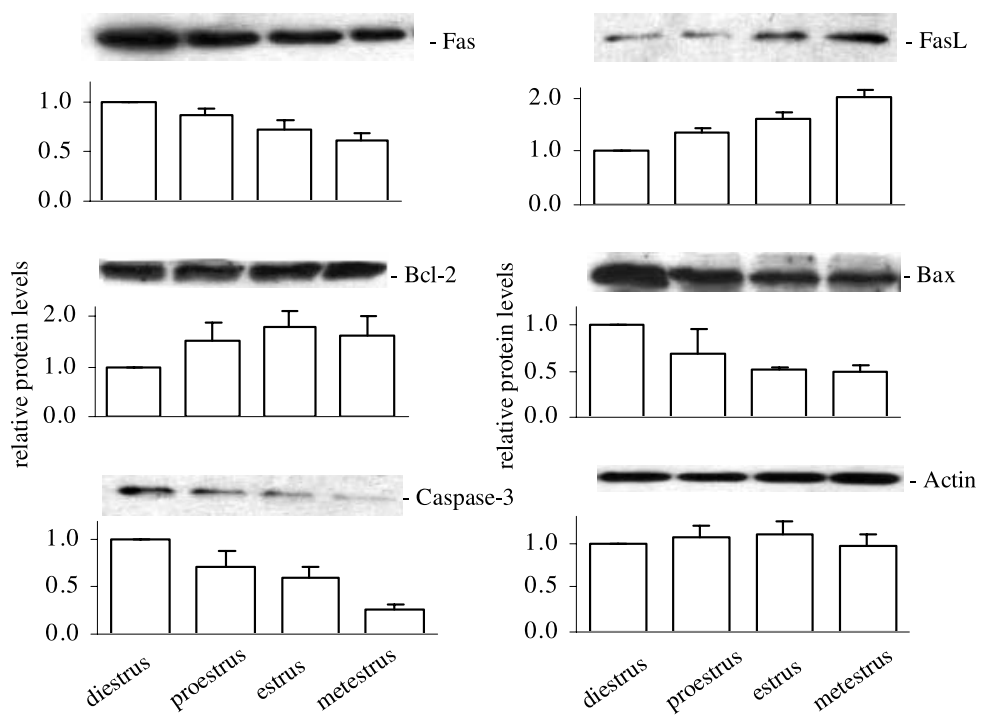

Figure 2 Expression of Fas, Fas ligand, Bcl-2, Bax and caspase-3 mRNA and protein in whole rat ovaries throughout the estrous cycle. Ovaries were obtained from rats sacrificed at four different stages of the estrous cycle and Fas, Fas ligand, Bcl-2, Bax and caspase- 3 mRNA and protein expression were determined by RT-PCR (A) and Western blotting (B), as described in Materials and Methods. (A) PCR products are visualized on agarose gels stained with ethidium bromide. Detection of GAPDH mRNA transcripts served as a positive control for amplification. Representative figures from three independent experiments are shown. (B) Western blot analysis of apoptotic and anti-apoptotic proteins. The panels above the graphs show a representative Western blot for each protein. The graphs represent a histogram of densitometric analysis of the immunoblots for each protein. The data were obtained from three independent experiments. Relative protein levels are expressed as mean density ratio \pm S.E.M., relative to the diestrus value on the same blot, which were quantified by analysis of density intensity using Quantity One software. Actin protein immunoblot staining served as a positive (loading) control.

(Fig. 2). As shown in fig. 2A, mRNAs of all Fas signalling molecules studied were detected at all stages during the estrous cycle. The amplified PCR products were of the expected size, i.e. Fas (282 bp), Fas ligand (491 bp), caspase-3 (282 bp), Bcl-2 (349 bp), Bax (301 bp) and GAPDH (318 bp). The negative controls (cDNA synthesis performed without RT or without template) revealed no expression for any of the investigated target sequences (data not shown). Western blot analysis revealed variations in the amounts of Fas $(45 \mathrm{kDa})$, Fas ligand (40 kDa), caspase-3 (32 kDa), Bcl-2 (26 kDa) and Bax $(22 \mathrm{kDa})$ protein during the estrous cycle (Fig. 2B). Fas, caspase- 3 and Bax protein levels were maximal at diestrus and decreased towards metestrus. In contrast, Fas ligand 
Table 1 Localization of various apoptotic proteins in the rat ovary

\begin{tabular}{|c|c|c|c|c|c|c|}
\hline & Fas & Fas ligand & Bcl-2 & Bax & Pro-caspase-3 & Active caspase- 3 \\
\hline \multicolumn{7}{|l|}{ Preantral follicles } \\
\hline Healthy granulosa & - & - & + & $-/+$ & ++ & - \\
\hline Health theca & $-/+$ & + & + & + & ++ & - \\
\hline Atretic theca & ++ & ++ & $-/+$ & ++ & ++ & $-/+$ \\
\hline \multicolumn{7}{|l|}{ Antral follicles } \\
\hline Healthy granulosa & $-/+$ & - & + & $-/+$ & ++ & - \\
\hline Atretic granulosa & + & $-/+$ & $-/+$ & $-/+$ & ++ & + \\
\hline Atretic theca & ++ & ++ & $-/+$ & ++ & ++ & $-/+$ \\
\hline \multicolumn{7}{|l|}{ OSE } \\
\hline Surface & + & $-/+$ & + & $-/+$ & ++ & - \\
\hline At postovulatory site & + & + & + & + & + & + \\
\hline \multicolumn{7}{|l|}{ Corpora lutea } \\
\hline
\end{tabular}

Immunohistochemical staining intensity: absent $(-)$, faint $(-/+)$, moderate $(+)$, high $(++)$.

and Bcl-2 protein levels were lowest at diestrus. Fas ligand protein levels increased towards metestrus, whereas Bcl-2 protein levels rose to a slightly lesser degree towards proestrus (Fig. 2B).

\section{Immunolocalization of the Fas system during follicular development}

To study the cellular distribution of Fas receptor and signalling molecules, immunohistochemistry was performed on ovarian sections. The localization and the intensity of the immunostaining for the various proteins of the Fas system in the ovary have been summarized in Table 1. Differences in immunostaining patterns were observed in healthy follicles at various stages of follicular growth (Fig. 3 and Fig. 4). In healthy follicles, immunostaining for Fas was detected in theca cells of secondary follicles onwards (Fig. 3A), whereas faint and inconsistent Fas staining appeared in granulosa cells at the early antral stage of follicular development (Table 1, staining not shown). Fas ligand immunoreactivity was present in theca cells, but absent in granulosa cells of healthy follicles throughout most of follicular development (Fig. 4A), though at proestrous some Fas ligand staining was observed in preovulatory follicles in the mural granulosa cells close to the basal membrane (Fig. 4A, insert). Bax immunostaining was also predominantly found in theca cells (Table 1, staining not shown). In granulosa cells, Bax immunoreactivity was faint and restricted to secondary and antral follicles (Table 1, staining not shown). Bcl-2 (Fig. 3C and 4B) and procaspase-3 (Fig. 3B) immunostaining was present in granulosa and theca cells of healthy follicles at all stages of development, though more fre- quently present in dominant preovulatory follicles compared with smaller antral follicles. The number of cells staining positively for the spliced active form of caspase-3 as well as showing TUNEL activity was negligible in healthy follicles (Table 1, staining not shown).

In atretic follicles, however, TUNEL labelling and immunoreactivity for active caspase-3 were often observed, predominantly in the apoptotic granulosa cells around the antral region but also in some scattered apoptotic theca cells (Fig. 4E and Fig. 4F). This increase in active caspase- 3 staining and TUNEL labelling, occurring after the onset of atresia, was accompanied by increased staining intensity for Fas (Table 1, staining not shown) and Fas ligand (Fig. 3F) in granulosa cells. Fas (Table 1, staining not shown) and Fas ligand (Fig. 3F) staining was even more intense in theca cells of atretic follicles, which was accompanied by enhanced Bax staining (Fig. 3E). Moreover, the immunostaining for Bax (in theca cells only), Fas and Fas ligand (in particular in theca cells, but also in granulosa cells), and active caspase-3 and TUNEL labelling (mainly in granulosa cells) appeared to be more intense and widespread in severely atretic follicles (Table 1 and e.g. Fig. 3F and Fig. 4C,F) compared with moderately atretic follicles (Table 1 and Fig. 3E). In contrast, the intensity of the staining of the anti-apoptotic protein Bcl-2 declined through the progressive stages of atresia in both granulosa and theca cells (Fig. 3D). Immunostaining for procaspase-3 was uniform throughout follicular development (Table 1 and Fig. 3B) and its relatively high level in both granulosa and theca cells was not influenced by advancing atresia (Table 1 and Fig. 4D). There were no differences in the distribution or intensity of immunostaining patterns of above studied apoptotic proteins in 

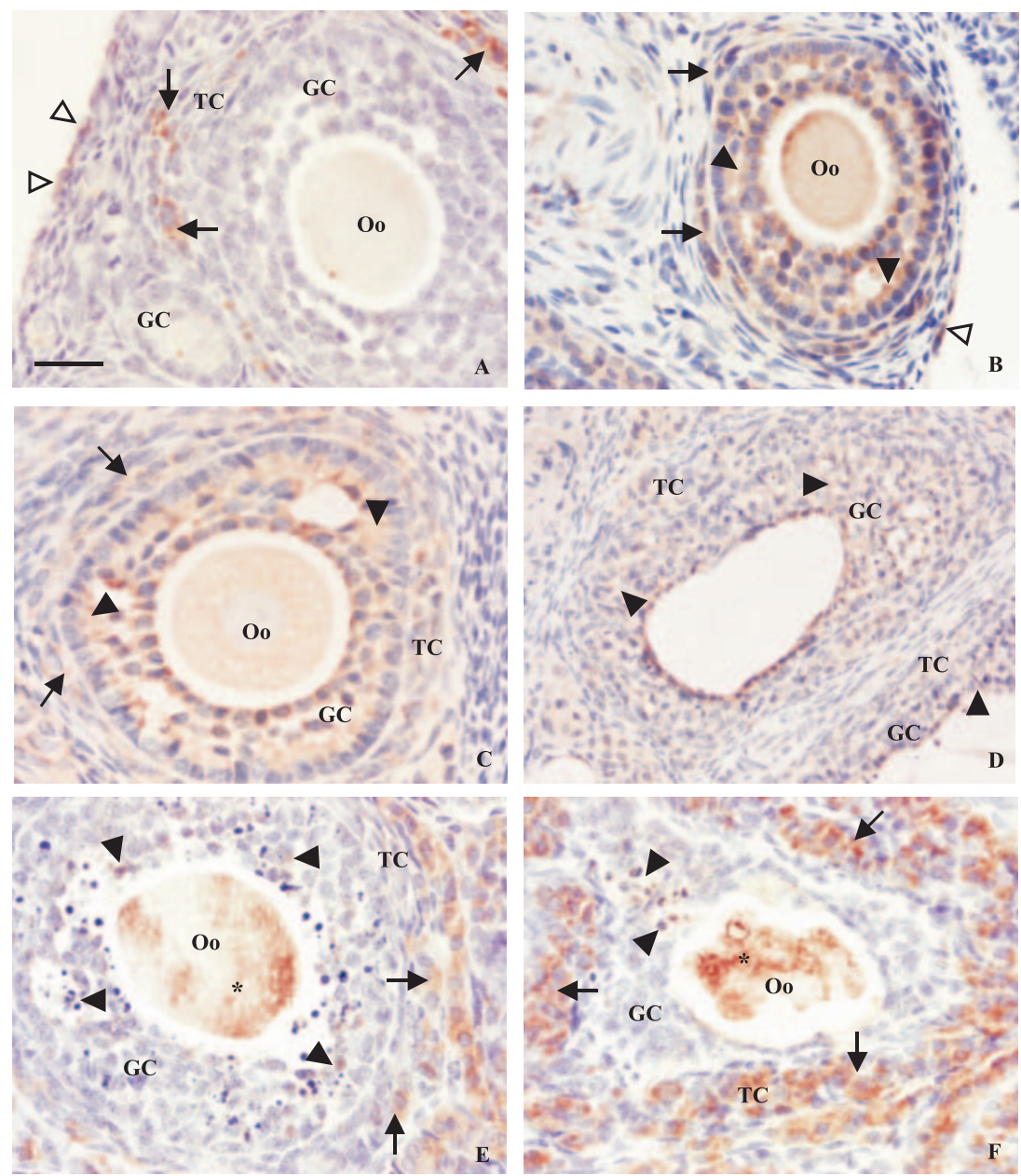

Figure 3 Immunohistochemical localization of various proteins involved in apoptosis in preantral follicles of cycling rats. Positive staining is shown as brown colouring of the cyctoplasm of the cells. (A-C) Healthy preantral follicles; Fas (A) immunostaining was found in theca cells but not in granulosa cells, whereas procaspase-3 (B) and $\mathrm{Bcl}-2$ (C) were observed in both granulosa and theca cells. D-F) In atretic preantral follicles; less $\mathrm{Bcl}-2$ immunopositive cells were observed (D), while Bax (E) and Fas ligand (F) immunostaining was now also present in some granulosa cells of both moderately (E) and severely (F) atretic follicles. The immunohistochemical labelling experiments were repeated at least six times with similar results. Theca cells (TC; arrows), granulosa cells (GC; arrowheads), oocytes (Oo), OSE (open arrowheads). Bar $=20 \mu \mathrm{m}(\mathrm{A}-\mathrm{C}, \mathrm{E}, \mathrm{F})$ or $40 \mu \mathrm{m}(\mathrm{D})$.

follicles that had become atretic at the various stages of follicular development (Table 1, Fig. 3D-F and Fig. 4C-E).

\section{Immunolocalization of the Fas system during ovulation}

In ovarian surface epithelial (OSE) cells, Fas (Fig. 3A and Fig. 5A), Bcl-2 (Fig. 5C) and procaspase-3 (Fig. 5E) immunostaining was generally observed throughout the entire estrous cycle (for summary of data see Table 1). In contrast, active caspase-3 immunoreactivity was observed only during estrus in some OSE cells at the postovulatory site (Fig. 5F). Immunoreactivity for Fas ligand (Fig. 5B) and Bax (Fig. 5D) was heterogeneous, but in general, more frequently observed in OSE cells that lined the postovulatory site during estrus compared with OSE cells lining other areas of the ovary (Table 1, staining not shown).

\section{Immunolocalization of the Fas system during luteolysis}

The age of the corpora lutea was determined on basis of their morphology, as described by Greenwald \& Rothchild (1968) and Erickson et al. (1993). Briefly, 

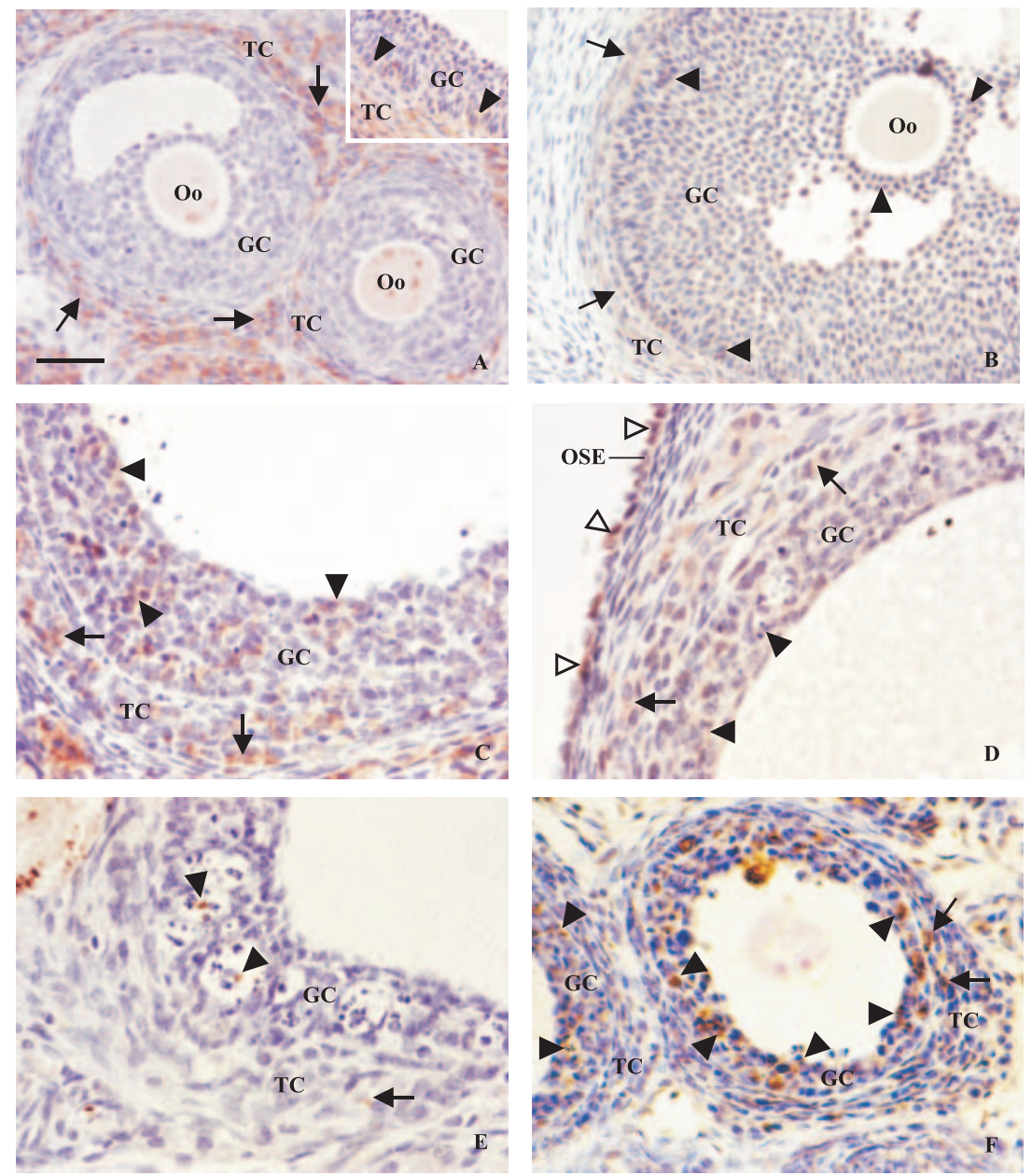

Figure 4 Immunohistochemical localization of various proteins involved in apoptosis in antral follicles of cycling rats. Positive staining is shown as brown colouring of the cytoplasm of the cells. (A-B) Healthy antral follicles; Fas ligand (A) immunostaining was observed in theca cells only, though at proestrous some Fas ligand was observed in the mural granulosa cells of preovulatory follicles close to the basal membrane (insert), whereas $\mathrm{BCl}-2$ (B) was present in both granulosa and theca cells. (C-F) Atretic preantral follicles; Fas (C) and procaspase-3 (D) immunostaining are present in both granulosa and theca cells; staining for active caspase-3 (E) and TUNEL labelling (F) is often observed in granulosa with condensed nuclei as well as in some apoptotic theca cells. The immunohistochemical labelling experiments were repeated at least six times with similar results. Theca cells (TC; arrows), granulosa cells (GC; arrowheads), oocytes (Oo), OSE (open arrowheads).

Bar $=20 \mu \mathrm{m}(\mathrm{C}-\mathrm{E})$ or $40 \mu \mathrm{m}(\mathrm{A}, \mathrm{B}, \mathrm{F})$.

corpora lutea derived from the most recent ovulation, consisted mainly of large luteal cells (large cells with a characteristic large round to oval nucleus) with only a minor number of fibroblasts (identified by the presence of an elongatd nucleus) and apoptotic cells. These were classified as new corpora lutea of the first generation. The regressing corpora lutea of the previous estrous cycles were assigned as corpora lutea of the second, third and later generations. Corpora lutea of the second generation were larger than corpora lutea of the first generation and contained not only luteal cells but also patches with significant numbers of fibroblasts, leukocytes (identified by a small compact nucleus and a relatively small amount of cytoplasm) and apoptotic cells. Corpera lutea of the third and later generations (two or more cycles old) were readily identified by their clearly smaller size compared with the first two generations, high numbers of fibroblasts as well as many apoptotic cells.

Immunoreactivity for Fas, Fas ligand, Bcl-2 and Bax, pro- and active caspase- 3 protein was always present in all corpora lutea, independent of the stage of development. However, their immunostaining patterns changed during 


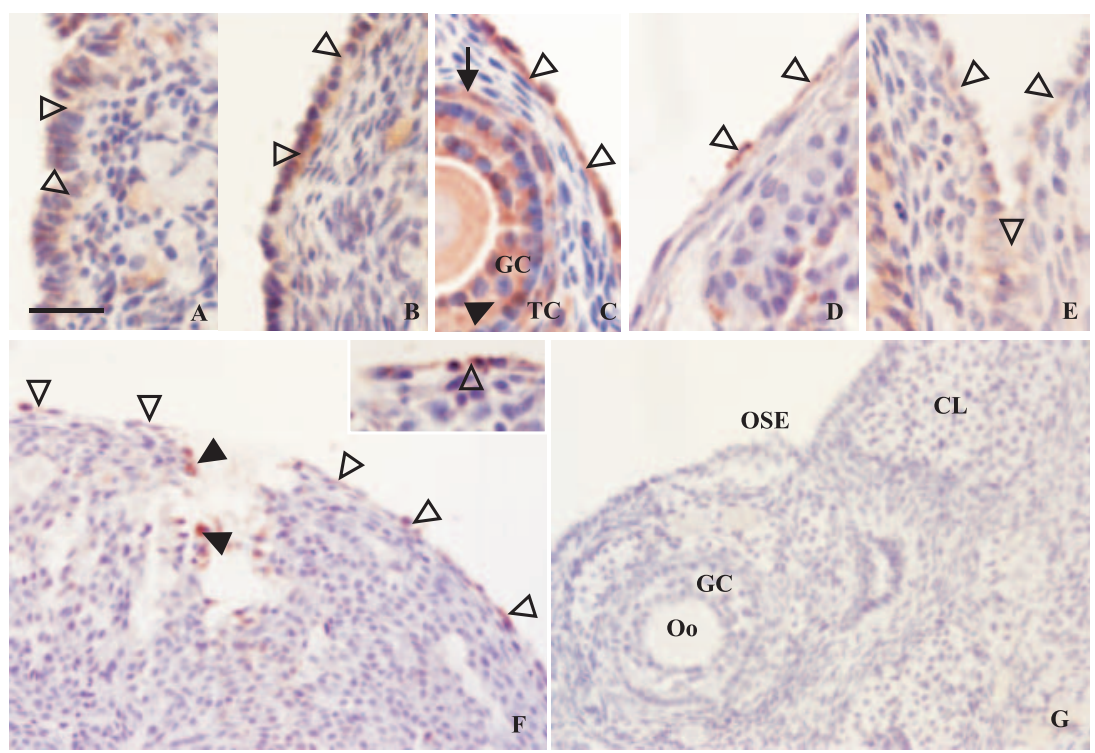

Figure 5 Immunohistochemical localization of various proteins involved in apoptosis in ovarian surface epithelial cells (OSE) of cycling rats. Positive staining is shown as brown colouring of the cytoplasm of the cells. (A-E) On the ovarian surface; flat-to-columnar OSE cells show a clear positive immunostaining for Fas (A), Fas ligand (B), Bcl-2 (C) and procaspase-3 (E), while immunoreactivity for Bax (D) was mainly restricted to OSE cells at the postovulatory site during estrus. (F) At the time of estrus, at the postovulatory site, some OSE cells had now become immunopositive for active caspase-3 (see also insert) as well. (G) Control ovarian section incubated with normal rabbit serum instead of primary antibody. The immunohistochemical labelling experiments were repeated at least six times with similar results. Theca cells (TC; arrows), granulosa cells (GC; arrowheads), oocytes (Oo), OSE (open arrowheads), corpora lutea (CL). Bar $=10 \mu \mathrm{m}$ (A-E and insert of F), $40 \mu \mathrm{m}$ (F) or $100 \mu \mathrm{m}(\mathrm{G})$.

luteal development. In the new corpora lutea of the first generation, many luteal cells stained positively for both Fas ligand (Fig. 6A) and Bcl-2 (Table 1, staining not shown) at metestrus, while in the corpora lutea of later generations, less luteal cells were positive for Fas ligand and $\mathrm{Bcl}-2$ (Table 1, staining not shown). Additionally, we observed a change in the histological localization of Fas ligand during luteal regression. In corpora lutea of the first generation, Fas ligand was predominantly localized in the luteal cells, whereas in corpora lutea of later generations, Fas ligand was less frequently observed in luteal cells and more often in patches consisting largely of infiltrating leukocytes. The number of luteal cells that showed Bax (Fig. 6B), Fas (Fig. 6C-D), pro- and active caspase-3 (Fig. 6E) immunostaining increased with the age of the corpora lutea.

\section{Discussion}

This is the first study in which the expression and localization of various components of the Fas apoptotic machinery have been examined by RT-PCR, Western blot analysis and immunohistochemistry throughout the estrous cycle in the rat ovary. Fas, Fas ligand, caspase-3, Bcl-2 and Bax mRNA expression and protein levels were detected in all ovarian tissue extracts, though the amount of protein varied with the phase of the estrous cycle. Fas, Bax and caspase- 3 protein levels reached a maximum around diestrus and steadily decreased thereafter towards metestrus. In contrast, Fas ligand and Bcl-2 protein levels were lowest at diestrus and increased, in particular Fas ligand, towards metestrus. We speculate that the reduced levels of the apoptotic proteins Fas, Bax and caspase-3, and to a lesser extend the increased protein levels of Fas ligand and the anti-apoptotic protein $\mathrm{Bcl}-2$ around the time of ovulation, may reflect a physiological survival mechanism to ensure ovulation of the dominant follicles and subsequent corpus luteum formation. Indeed, immunohistochemistry revealed that Bcl-2 was more frequently observed in dominant preovulatory healthy follicles. At estrus, following ovulation both Fas ligand and Bcl-2 were prominently present in the newly formed corpora lutea, while in older generations of corpora lutea, the immunostaining of these proteins diminished. In addition, the relatively prominent immunostaining at diestrus of the apoptotic proteins Fas, Bax and caspase- 3 in corpora lutea of the third and later generations, may explain the 

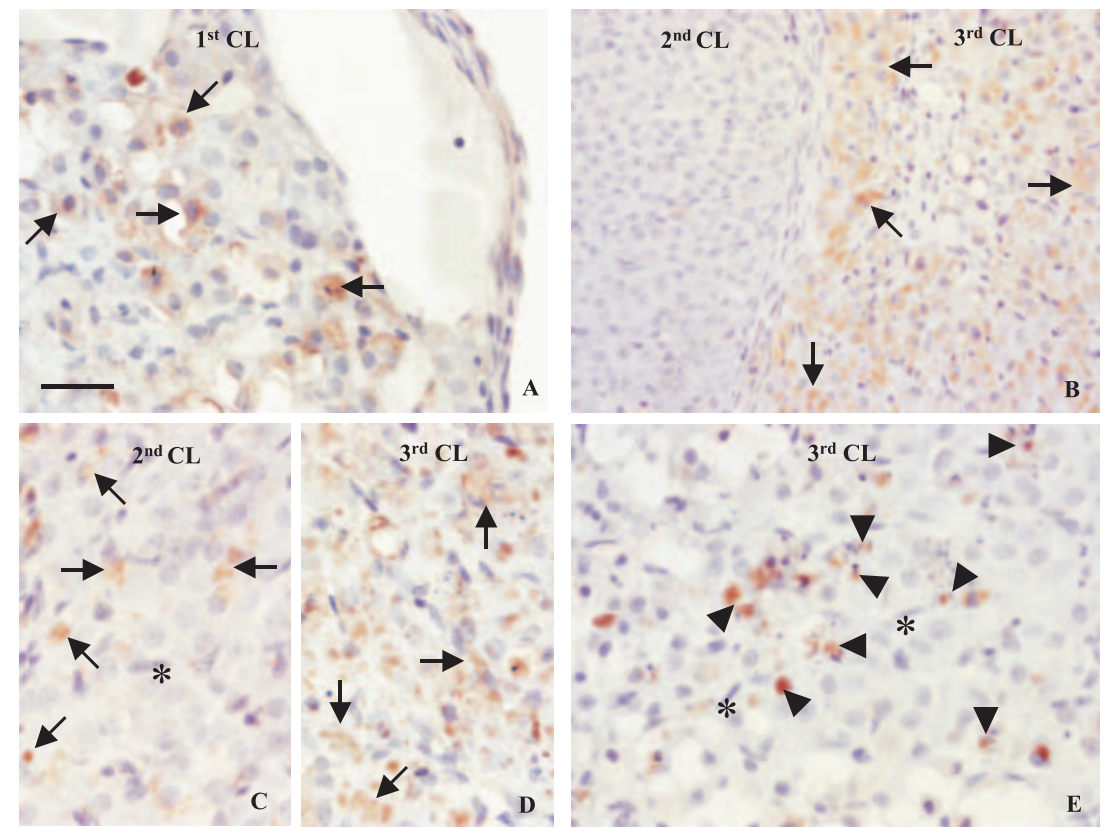

Figure 6 Immunohistochemical localization of various apoptotic proteins in corpora lutea of cycling rats. Positive staining is shown as brown colouring of the cytoplasm of the cells. (A) Early corpus luteum of the first generation $\left(1^{\text {st }} \mathrm{CL}\right)$ at metestrus; clear immunostaining for Fas ligand is present in large luteal cells. (B-D) Corpora lutea of different ages; immunostaining for Bax (B) and Fas $(C-D)$ was faint in corpora luteua of the first and second generation $\left(2{ }^{\text {nd }} C L\right)$ while high in corpora lutea of the third generation $\left(3^{\text {rd }} C L\right)$. $(E)$ Corpus luteum of the third generation; active caspase- 3 immunopositive cells often had condensed and fragmented nuclei (arrowheads) that are indicative for apoptosis. Fibroblasts, characterized by their elongated nuclei, are indicated by asterisks. The immunohistochemical labelling experiments were repeated al least six times with similar results. Bar $=20 \mu \mathrm{m}(\mathrm{A}, \mathrm{C}-\mathrm{E})$ or $40 \mu \mathrm{m}(\mathrm{B})$.

increased levels of these proteins at this stage of the estrous cycle, as observed by Western blot analysis.

In follicles, Fas ligand expression in granulosa cells was limited to some mural granulosa cells at proestrus, whereas this factor was predominantly localized in theca cells throughout most stages of follicular development. Theoretically, Fas ligand expressing theca cells can mediate apoptosis through binding to Fas receptor either on leukocytes thereby withstanding an attack by leukocytes (Kim et al. 1998), or to adjacent Fas-expressing theca cells. Although rat thecal/interstitial cells do undergo Fasinduced apoptosis in vitro (Foghi et al. 1998), we as well as some other groups (e.g. Palumbo \& Yeh 1994) observed only a few apoptotic, TUNEL-positive, theca cells in atretic follicles, despite the abundant presence of Fas. Some of these apoptotic theca cells also stained positively for active caspase-3, which is in line with observations in humans (Matikainen et al. 2001) but in contrast to studies in mice (Fenwick \& Hurst 2002). This suggests that theca cells in vivo are moderately resistant to Fas-induced apoptosis, though the mechanism by which these cells can resist apoptosis is at present not clear. Theca cells of both healthy and atretic follicles displayed intense positive immunostaining for procaspase-3, implicating that the resistance to apoptosis is not a consequence of the absence of caspase-3. Apparently the activation of caspase-3 in theca cells is a tightly regulated process and seems differentially regulated from caspase-3 activation in for instance granulosa cells.

The majority of the TUNEL positive follicular cells as well as active caspase-3 staining were restricted to apoptotic granulosa cells in atretic follicles, which is consistent with earlier observations (Boone \& Tsang 1998). Although the intensity of Fas staining in granulosa cells was increased in atretic follicles, Fas ligand and Bax staining remained faint in these granulosa cells. The physiological significance of this observation is not known and emphasizes our relatively limited understanding of the factors and mechanism that may cause apoptosis in granulosa cells in follicles at the onset of atresia. As will be discussed below, some recent studies suggest that growth factors and steroids may play a role in the initiation of granulosa cell apoptosis. On the other hand, as Fas ligand also exists in a soluble form that can move freely among cells, it is possible that a yet unknown factor may trigger a switch from membrane-bound Fas ligand to the soluble 
form in theca cells, which in turn may diffuse to the granulosa cells. At the same time, Fas expression in granulosa cells of these follicles is enhanced and binding of soluble Fas ligand could then trigger apoptosis in these cells.

In the ovary, the loss of secretion of crucial hormonal survival factors is thought to stimulate atresia. For example, the gonadotrophins FSH and LH have been shown to inhibit apoptosis in cultured preovulatory follicles (Chun et al. 1994), possibly by suppressing Fas expression (Bridgham \& Johnson 2001). Moreover, reduced FSH exposure leads to caspase-mediated apoptosis in granulosa cells at the early antral stage of follicular development, a process which was associated with increased levels of Fas and Fas ligand in the rat ovary (Kim et al. 1998). These observations are extended by our immunohistochemical data showing that Fas and Fas ligand were faintly present to absent in granulosa cells of healthy antral follicles during the follicular phase of the estrous cycle when gonadotrophins levels were high.

Beside gonadotrophins, growth factors and sex steroids are important local regulators of follicular survival. In cultured preovulatory follicles, the growth factors EGF, TGF- $\beta$, bFGF and IGF-I as well as the steroid estradiol, have been shown to inhibit apoptosis (Chun et al. 1994). The exact mechanism how these growth factors inhibit apoptosis has only been partially elucidated. EGF, TGF- $\beta$ and bFGF may inhibit granulosa cell apoptosis through a tyrosine kinase dependent pathway (Tilly et al. 1992). A link with the Fas system was made in a more recent in vitro study in which Quirk and colleagues reported that these produced growth factors locally in the ovary that acted by inhibiting Fas ligand-induced apoptosis, an effect that was apparently not directly related to the level of Fas expression (Quirk et al. 2000a). In another study, the same group demonstrated that IGF-1 inhibits Fas ligand-induced apoptosis by activation of Akt kinase, which in turn can inactivate the caspases 8 and 9 , and some proapoptotic members of the Bcl-2 family, all factors involved in Fas ligand-induced apoptosis (Hu et al. 2004). Estrogens have been proposed to enhance Fas ligand expression, a process that could be antagonized by the estrogen receptor inhibitor, tamoxifen (Sapi et al. 2002). In concert with these data, the present study showed that the amount of Fas ligand in ovarian tissue extracts was elevated shortly after estrogen dominance. There are indications that another steroid, progesterone, also plays a role in the regulation of granulosa cell apoptosis. The appearance of progesterone receptors on the surface of granulosa cells made these cells insensitive to Fas ligand-induced apoptosis, an effect that could be counteracted by treatment with the progesterone receptor antagonist RU 486 (Quirk et al. 2004). All these studies point to the important role of locally produced factors in the regulation of follicular atresia, in most cases through either direct or indirect interaction with the Fas system. On the other hand, a possible role of other mechanisms in the control of follicular atresia, e.g. such as by influencing intracellular calcium levels (Peluso 2003), can at present not be excluded.

In our study, the $\mathrm{Bcl}-2$ family proteins, $\mathrm{Bcl}-2$ and $\mathrm{Bax}$, were observed in both granulosa and theca cells throughout all stages of follicular development. In the primate and human ovary, Bcl-2 and Bax expression has been observed in granulosa cells as well, but not in theca cells (Vaskivuo et al. 2001, Depalo et al. 2003). This suggests that there may be differences among species concerning the presence and function of Bcl-2 family members in the ovary, and that one must be cautious in extrapolating the results obtained in the rat to other species.

The staining intensity of the anti-apoptotic protein Bcl-2 declined through the progressive stages of atresia in both granulosa and theca cells. In contrast, a higher degree of expression of pro-apoptotic proteins, i.e. Fas and Fas ligand (in particular in theca cells, but also in granulosa cells), Bax (only in theca cells) active caspase-3 and TUNEL labelling (mainly in granulosa cells) was observed in atretic follicles versus healthy follicles. The staining for these proteins appeared to be more intense and widespread with advancing atresia. These findings suggest that the expression of Fas-related proteins is increased as an integral part of the apoptotic process and is not due to follicular growth, since a similar apoptotic executioner program occurs among all stages of follicular atresia. These observations also suggest that the Fas death receptor in theca cells of atretic follicles may act along with the Bcl-2 family proteins to elicit an apoptotic response, characteristic for type II cells. On the other hand, theca cells do not undergo massive apoptosis like granulosa cells, suggesting that a regulatory mechanism determines theca cell susceptibility for Fas signalling activation and cell death.

Little is known about the role of the Fas system in OSE cells. OSE cells have been suggested to undergo cycles of proliferation and degeneration that are associated with the ovulatory process. In ewes, it has been demonstrated that prior to ovulation, OSE cells surrounding the follicles destined to rupture, are highly exposed to both inflammatory agents and reactive oxidants, a condition which is accompanied by increased apoptosis and upregulation of p53 (Murdoch et al. 2001, Murdoch \& Van Kirk 2002). In contrast, OSE cells located along the margins of ruptured follicles survive and express anti-apoptotic $\mathrm{Bcl}-2$ protein, which probably functions to compensate for the insult following ovulation (Murdoch et al. 2001). A novel observation in the present study is that Bcl-2, Fas and procaspase- 3 are moderately expressed in OSE cells throughout the estrous cycle at locations where apoptosis of these cells was negligible. In addition, Fas ligand and Bax appeared to be more frequently expressed in OSE cells that lined the follicles destined to ovulate, than in OSE cells covering the remaining part of the ovary. OSE cells expressing active caspase- 3 were observed only at the postovulatory site. In vitro studies have shown that 
cultured mouse OSE cells undergo apoptosis in response to Fas activation when pre-treated with IFN $\gamma$ (Quirk et al. 1997). Hence, we would like to hypothesize that activation of the Fas death receptor pathway is blocked in OSE cells, until ovulation. The appearance of Fas ligand and Bax in OSE cells that surround the preovulatory follicles prior to ovulation, may in turn elicit the execution of apoptosis, indicating that Fas-induced signalling in apoptotic OSE cells is characteristic of type II cells (Krammer 1999). Based on our findings, we further hypothesize the following model for OSE cell survival associated with ovulation. Proteolytic factors, released prior to ovulation, may facilitate the rupture of the follicular stigma and induce apoptosis in OSE cells surrounding the apex of the follicle. The LH surge-initiated rise in progesterone may attribute to apoptosis of these damaged OSE cells (Murdoch et al. 2001, Murdoch \& Van Kirk 2002). Indeed, progesterone has been shown to enhance p53 expression in sheep OSE cells (Murdoch \& Van Kirk 2002) and to induce in vivo (Rodriguez et al. 1998) and in vitro OSE cell death via enhanced Fas/FasL signalling (Syed \& Ho 2003). On the other hand, the high levels of estrogens, released with the follicular fluid at the time of ovulation, may play a role in the survival of undamaged OSE cells next to the rupture site (Murdoch \& Van Kirk 2002), since in vitro studies have demonstrated that high concentrations of estrogens increase proliferation and suppress apoptosis in OSE cells (Murdoch \& Van Kirk 2002, Ho 2003).

It has been well established that the Fas system may control structural involution of the corpora lutea (Roughton et al. 1999, Taniguchi et al. 2002). The incidence of luteal cell death appeared to be markedly delayed in mice lacking functional Fas, Fas ligand (Sakamaki et al. 1997), Bax (Perez et al. 1999) or caspase-3 (Carambula et al. 2002), whereas in vitro Fas ligand or agonistic-Fas antibodies-induced luteal cell death (Quirk et al. 2000b. Carambula et al. 2003). In the present study, the immunostaining intensity of various components of the Fas signalling pathway, i.e. Fas, Bax, pro- and active caspase-3, increased in luteal cells as the corpora lutea advanced in age, when the luteal cells lose their ability to secrete progesterone (Kuranaga et al. 2000b). In vitro studies have demonstrated that luteothropic factors, like progesterone and human chorionic gonadotrophin, suppressed apoptosis in luteal cells by lowering Fas, Fas ligand, Bax and/or p53 expression (Matsubara et al. 2000, Sugino et al. 2000, Okuda et al. 2004). All these observations strongly suggest that in luteal cells of the rat the Fas death receptor acts in concert with a balance of pro- and antiapoptotic Bcl-2 family members in luteal cells, which is in line with previous observations in various other species (Kondo et al. 1996, Sakamaki et al. 1997, Sugino et al. 2000). Therefore, these cells are presumably type II cells.

Increased levels of luteolytic factors, such as prolactin (Gaytan et al. 2001) and $\mathrm{PGF}_{2 \alpha}$ (Yadav et al. 2005) have been shown to stimulate infiltration of Fas ligand expressing leukocytes into the regressing corpora lutea, which in turn could induce apoptosis in Fas-expressing luteal cells (Kuranaga et al. 2000a). Consistent with this assumption, we observed Fas ligand expression in infiltrating leukocytes in the regressing corpora lutea of the second and later generations. Additionally, we found a change in histological localization of Fas ligand during luteal regression, which has not been reported before. In newly formed corpora lutea, Fas ligand was predominantly localized in the luteal cells, while in the older corpora lutea of the third generation, expression was diminished in these cell types. We speculate that the appearance of Fas ligand in luteinized cells in newly formed corpora lutea may function to protect these cells against programmed cell death by inducing apoptosis of Fas expressing infiltrating leukocytes (Kuranaga et al. 2000a).

In conclusion, apoptosis in the reproductive tissues of both males and females is thought to occur after withdrawal of crucial hormonal support. Unlike the prostate and testis, however, apoptosis in the ovary and the uterus is linked to estrous cycle driven variations in hormonal secretion (Martimbeau \& Tilly 1997). The reduced levels of the apoptotic proteins Fas, Bax and caspase-3, and the slightly higher levels of Fas ligand and the anti-apoptotic protein $\mathrm{Bcl}-2$ in the rat ovary around the time of ovulation may reflect physiological survival mechanisms to ensure ovulation of the dominant follicles, corpus luteum formation and OSE cell repair. Hence, apoptosis of the various ovarian cell types seems to depend on hormonal support as well as on the presence of the Fas system and Bcl-2 family members.

\section{Acknowledgements}

We would like to thank Dr D Duijsings and E Verbraak (Department of Biochemistry and Cell Biology, Utrecht University) for their valuable contribution to the PCR experiments, and Prof. W Stoorvogel and Prof. W den Otter (Department of Biochemistry and Cell Biology, Utrecht University) for reviewing this manuscript. This work was supported financially by Wageningen University. The authors declare that there is no conflict of interest that would prejudice the impartiality of this scientific work.

\section{References}

Boone DL \& Tsang BK 1998 Caspase-3 in the rat ovary: localization and possible role in follicular atresia and luteal regression. Biology of Reproduction 58 1533-1539.

Bradford MM 1976 A rapid and sensitive method for the quantification of microgram quantities of protein utilizing the principle of protein dye binding. Analytical Biochemistry 72 248-254.

Bridgham JT \& Johnson AL 2001 Expression and regulation of Fas antigen and tumor necrosis factor receptor type I in hen granulosa cells. Biology of Reproduction. 65 733-739. 
Carambula SF, Matikainen T, Lynch MP, Flavell RA, Goncalves PB, Tilly JL \& Rueda BR 2002 Caspase-3 is a pivotal mediator of apoptosis during regression of the ovarian corpus luteum. Endocrinology 143 1495-1501.

Carambula SF, Pru JK, Lynch MP, Matikainen T, Goncalves PB, Flavell RA, Tilly JL \& Rueda BR 2003 Prostaglandin F2 alphaand FAS-activating antibody-induced regression of the corpus luteum involves caspase- 8 and is defective in caspase- 3 deficient mice. Reproductive Biology and Endocrinology 115.

Cataldo NA, Dumesic DA, Goldsmith PC \& Jaffe RB 2000 Immunolocalization of Fas and Fas ligand in the ovaries of women with polycystic ovary syndrome: relationship to apoptosis. Human Reproduction 15 1889-1897.

Chun SY, Billig H, Tilly JL, Furuta I, Tsafriri A \& Hsueh AJ 1994 Gonadotropin suppression of apoptosis in cultured preovulatory follicles: mediatory role of endogenous insulin-like growth factor I. Endocrinology 135 1845-1853.

Depalo R, Nappi L, Loverro G, Bettocchi S, Caruso ML, Valentini AM \& Selvaggi L 2003 Evidence of apoptosis in human primordial and primary follicles. Human Reproduction 18 2678-2682.

Dharma SJ, Kelkar RL \& Nandedkar TD 2003 Fas and Fas ligand protein and mRNA in normal and atretic mouse ovarian follicles. Reproduction. 126 783-789.

Duvigneau JC, Hartl RT, Teinfalt M \& Gemeiner M 2003 Delay in processing porcine whole blood affects cytokine expression. Journal of Immunological Methods 272 11-21.

Erickson GF, Nakatani A, Ling N \& Shimasaki S 1993 Insulin-like growth factor binding protein-3 gene expression is restricted to involuting corpora lutea in rat ovaries. Endocrinology 133 1147-1157

Fenwick MA \& Hurst PR 2002 Immunohistochemical localization of active caspase- 3 in the mouse ovary: growth and atresia of small follicles. Reproduction. 124 659-665.

Foghi A, Ravandi A, Teerds KJ, van der Donk H., Kuksis A \& Dorrington J 1998 Fas-induced apoptosis in rat thecal/interstitial cells signals through sphingomyelin-ceramide pathway. Endocrinology 139 2041-2047.

Gaytan F, Bellido C, Morales C \& Sanchez-Criado JE 2001 Cyclic changes in the responsiveness of regressing corpora lutea to the luteolytic effects of prolactin in rats. Reproduction. 122 411-417.

Greenwald GS \& Rothchild I 1968 Formation and maintenance of corpora lutea in laboratory animals. Journal of Animal Science 27 (Suppl 1) 139-162.

Guo MW, Mori E, Xu JP \& Mori T 1994 Identification of Fas antigen associated with apoptotic cell death in murine ovary. Biochemical and Biophysical Research Communications 203 1438-1446.

Hakuno N, Koji T, Yano T, Kobayashi N, Tsutsumi O, Taketani Y \& Nakane PK 1996 Fas/APO-1/CD95 system as a mediator of granulosa cell apoptosis in ovarian follicle atresia. Endocrinology $1371938-1948$.

Ho SM 2003 Estrogen, Progesterone and Epithelial Ovarian Cancer. Reproductive Biology and Endocrinology 173.

Hsueh AJ, Billig H \& Tsafriri A 1994 Ovarian follicle atresia: a hormonally controlled apoptotic process. Endocrine Reviews 15 707-724.

Hu C-L, Cowan RG, Harman RM \& Quirk SM 2004 Cell cycle progression and activation of Akt kinase are required for insulin-like growth factor I0 mediated suppression of apoptosis in granulosa cells. Molecular Endocrinology 18 326-338.

Kim JM, Boone DL, Auyeung A \& Tsang BK 1998 Granulosa cell apoptosis-induced at the penultimate stage of follicular development is associated with increased levels of Fas and Fas ligand in the rat ovary. Biology of Reproduction 58 1170-1176.

Kim JM, Yoon YD \& Tsang BK 1999 Involvement of the Fas/Fas ligand system in p53-mediated granulosa cell apoptosis during follicular development and atresia. Endocrinology 140 2307-2317.

Kimura K, Wakatsuki T \& Yamamoto M 1994 A variant mRNA species encoding a truncated form of Fas antigen in the rat liver. Biochemical and Biophysical Research Communications 198 666-674.
Kondo H, Maruo T, Peng X \& Mochizuki M 1996 Immunological evidence for the expression of the Fas antigen in the infant and adult human ovary during follicular regression and atresia. Journal of Clinical Endocrinology and Metabolism 81 2702-2710.

Krammer PH 1999 CD95(APO-1/Fas)-mediated apoptosis: live and let die. Advances in Immunology 71 163-210.

Kugu K, Ratts VS, Piquette GN, Tilly KI, Tao XJ, Martimbeau S, Aberdeen GW, Krajewski S, Reed JC, Pepe GJ et al. 1998 Analysis of apoptosis and expression of bcl-2 gene family members in the human and baboon ovary. Cell Death and Differentiation 5 67-76.

Kuranaga E, Kanuka H, Bannai M, Suzuki M, Nishihara M \& Takahashi M 1999 Fas/Fas ligand system in prolactin-induced apoptosis in rat corpus luteum: possible role of luteal immune cells. Biochemical and Biophysical Research Communications 260 167-173.

Kuranaga E, Kanuka H, Furuhata Y, Yonezawa T, Suzuki M, Nishihara M \& Takahashi M 2000a Requirement of the Fas ligand-expressing luteal immune cells for regression of corpus luteum. FEBS Letters 472 137-142.

Kuranaga E, Kanuka H, Hirabayashi K, Suzuki M, Nishihara M \& Takahashi M $2000 b$ Progesterone is a cell death suppressor that downregulates Fas expression in rat corpus luteum. FEBS Letters 466 279-282.

Markstrom E, Svensson EC, Shao R, Svanberg B \& Billig H 2002 Survival factors regulating ovarian apoptosis - dependence on follicle differentiation. Reproduction. 123 23-30.

Martimbeau S \& Tilly JL 1997 Physiological cell death in endocrine-dependent tissues: an ovarian perspective. Clinical Endocrinology 46 241-254.

Matikainen T, Perez GI, Zheng TS, Kluzak TR, Rueda BR, Flavell RA \& Tilly JL 2001 Caspase-3 gene knockout defines cell lineage specificity for programmed cell death signalling in the ovary. Endocrinology 142 2468-2480.

Matsubara H, Ikuta K, Ozaki Y, Suzuki Y, Suzuki N, Sato T \& Suzumori K 2000 Gonadotropins and cytokines affect luteal function through control of apoptosis in human luteinized granulosa cells. Journal of Clinical Endocrinology and Metabolism 85 1620-1626.

McGee EA \& Hsueh AJ 2000 Initial and cyclic recruitment of ovarian follicles. Endocrine Reviews 21 200-214.

Murdoch WJ \& McDonnel AC 2002 Roles of the ovarian surface epithelium in ovulation and carcinogenesis. Reproduction $123743-750$.

Murdoch WJ \& Van Kirk EA 2002 Steroid hormonal regulation of proliferative, p53 tumor suppressor, and apoptotic responses of sheep ovarian surface epithelial cells. Molecular and Cellular Endocrinology 186 61-67.

Murdoch WJ, Townsend RS \& McDonnel AC 2001 Ovulation-induced DNA damage in ovarian surface epithelial cells of ewes: prospective regulatory mechanisms of repair/survival and apoptosis. Biology of Reproduction 65 1417-1424.

Negoescu A, Lorimier P, Labat-Moleur F, Drouet C, Robert C, Guillermet C, Brambilla C \& Brambilla E 1996 In situ apoptotic cell labelling by the TUNEL method: improvement and evaluation on cell preparations. Journal of Histochemistry and Cytochemistry 44 959-968.

Okuda K, Korzekwa A, Shibaya M, Murakami S, Nishimura R, Tsubouchi M, Woclawek-Potocka I \& Skarzynski DJ 2004 Progesterone is a suppressor of apoptosis in bovine luteal cells. Biology of Reproduction 71 2065-2071.

Omezzine A, Chater S, Mauduit C, Florin A, Tabone E, Chuzel F, Bars R \& Benahmed M 2003 Long-term apoptotic cell death process with increased expression and activation of caspase- 3 and -6 in adult rat germ cells exposed in utero to flutamide. Endocrinology 144 648-661.

Palumbo A \& Yeh J 1994 In situ localization of apoptosis in the rat ovary during follicular atresia. Biology of Reproduction 51 888-895. 
Peluso JJ 2003 Basic fibroblast growth factor (bFGF) regulation of the plasma membrane calcium ATPase (PMCA) as part of an anti-apoptotic mechanism of action. Biochemical Pharmacology 66 1363-1369.

Perez GI, Robles R, Knudson CM, Flaws JA, Korsmeyer SJ \& Tilly JL 1999 Prolongation of ovarian lifespan into advanced chronological age by Bax-deficiency. Nature Genetics 21 200-203.

Quirk SM, Cowan RG \& Huber SH 1997 Fas antigen-mediated apoptosis of ovarian surface epithelial cells. Endocrinology $1384558-4566$

Quirk SM, Harman RM \& Cowan RG 2000a Regulation of Fas antigen (Fas, CD95)-mediated apoptosis of bovine granulosa cells by serum and growth factors. Biology of Reproduction 63 1278-1284

Quirk SM, Harman RM, Huber SC \& Cowan RG $2000 b$ Responsiveness of mouse corpora luteal cells to Fas antigen (CD95)-mediated apoptosis. Biology of Reproduction 63 49-56.

Quirk SM, Cowan RG \& Harman RM 2004 Progesterone receptor and the cell cycle modulate apoptosis in granulosa cells. Endocrinology 145 5033-5043.

Rodriguez GC, Walmer DK, Cline M, Krigman H, Lessey BA, Whitaker RS, Dodge R \& Hughes CL 1998 Effect of progestin on the ovarian epithelium of macaques: cancer prevention through apoptosis? Journal of the Society for Gynecological Investigation 5 271-276.

Roughton SA, Lareu RR, Bittles AH \& Dharmarajan AM 1999 Fas and Fas ligand messenger ribonucleic acid and protein expression in the rat corpus luteum during apoptosis-mediated luteolysis. Biology of Reproduction 60 797-804.

Sakamaki K, Yoshida H, Nishimura Y, Nishikawa S, Manabe N \& Yonehara S 1997 Involvement of Fas antigen in ovarian follicular atresia and luteolysis. Molecular Reproduction and Development 47 11-18.

Sapi E, Brown WD, Aschkenazi S, Lim C, Munoz A, Kacinski BM, Rutherford T \& Mor G 2002 Regulation of Fas ligand expression by estrogen in normal ovary. Journal of the Society for Gynecological Investigation 9 243-250.

Sato T, Irie S, Krajewski S \& Reed JC 1994 Cloning and sequencing of a cDNA encoding the rat Bcl-2 protein. Gene 140 291-292.

Scaffidi C, Fulda S, Srinivasan A, Friesen C, Li F, Tomaselli KJ, Debatin KM, Krammer PH \& Peter ME 1998 Two CD95 (APO-1/Fas) signalling pathways. EMBO Jounal 17 1675-1687.

Suda T, Takahashi T, Golstein P \& Nagata S 1993 Molecular cloning and expression of the Fas ligand, a novel member of the tumor necrosis factor family. Cell 75 1169-1178.
Sugino N, Suzuki T, Kashida S, Karube A, Takiguchi S \& Kato H 2000 Expression of Bcl-2 and Bax in the human corpus luteum during the menstrual cycle and in early pregnancy: regulation by human chorionic gonadotropin. Journal of Clinical Endocrinology and Metabolism 85 4379-4386.

Syed V \& Ho SM 2003 Progesterone-induced apoptosis in immortalized normal and malignant human ovarian surface epithelial cells involves enhanced expression of FasL. Oncogene 22 6883-6890.

Taniguchi H, Yokomizo Y \& Okuda K 2002 Fas-Fas ligand system mediates luteal cell death in bovine corpus luteum. Biology of Reproduction 66 754-759.

Teerds KJ \& Dorrington JH 1995 Immunolocalization of transforming growth factor alpha and luteinizing hormone receptor in healthy and atretic follicles of the adult rat ovary. Biology of Reproduction 52 500-508.

Tilly JL 2001 Commuting the death sentence: how oocytes strive to survive. Nature Reviews in Molecular Cell Biology 2 838-848.

Tilly JL, Billig H, Kowalski KI \& Hsueh AJ 1992 Epidermal growth factor and basic fibroblast growth factor suppress the spontaneous onset of apoptosis in cultured rat ovarian granulosa cells and follicles by a tyrosine kinase dependent mechanism. Molecular Endocrinology 6 1942-1950.

Tilly JL, Tilly KI, Kenton ML \& Johnson AL 1995 Expression of members of the bcl-2 gene family in the immature rat ovary: equine chorionic gonadotropin-mediated inhibition of granulosa cell apoptosis is associated with decreased bax and constitutive bcl-2 and bcl-xlong messenger ribonucleic acid levels. Endocrinology 136 232-241.

Vaskivuo TE, Anttonen M, Herva R, Billig H, Dorland M, te Velde ER, Stenback F, Heikinheimo M \& Tapanainen JS 2001 Survival of human ovarian follicles from fetal to adult life: apoptosis, apoptosis-related proteins, and transcription factor GATA-4. Journal of Clinical Endocrinology and Metabolism 86 3421-3429.

Yadav VK, Lakshmi G \& Medhamurthy R 2005 Prostaglandin F2 alpha-mediated activation of apoptotic signalling cascades in the corpus luteum during apoptosis: involvement of caspase-activated DNase. Journal of Biological Chemistry 280 10357-10367.

Received 18 August 2005

Accepted 16 November 2005 